\title{
JARINGAN SOSIAL PEMASARAN PADA KOMUNITAS NELAYAN TRADISIONAL BANTEN
}

\author{
Suwaib Amiruddin $\bowtie$ \\ Jurusan Administrasi Negara, Fakultas Ilmu Sosial \& Politik, Universitas Sultan Ageng Tirtayasa, \\ Indonesia
}

Permalink/DOI: http://dx.doi.org/10.15294/komunitas.v6i1.2949

\begin{tabular}{l} 
Article History \\
\hline Received : Desember 2013 \\
Accepted : Januari 2014 \\
Published : Maret 2014
\end{tabular}

\section{Keywords}

social networks; communities; marketing groups

\begin{abstract}
Abstrak
Nelayan tradisional memiliki karakteristik ketergantungan terhadap kondisi alam dan hasil tangkapan yang diperoleh. Selain itu ketergantungan terjadi pula pada aspek permodalan dan jaringan sosial pemasaran. Penelitian ini mengeksplorasi karakteristik nelayan tradisional, proses dan jaringan sosial pemasaran antar kelompok dan jaringan sosial pemasaran melalui Tempat Pelelangan Ikan (TPI). Penelitian ini menggunakan metode penelitian kualitatif. Informan penelitian adalah pemilik modal, pemilik perahu, nelayan, petugas TPI. Hasil penelitiannya adalah bahwa karakteristik komunitas nelayan tradisional di Lontar melakukan kegiatan penangkapan ikan berdasarkan pada jenis alat tangkap yang dimiliki terdiri dari rejung, jaring insang, ikan karang, rakek (kerang) kapasitas mesin perahu adalah 15-17pk. Jangkauan jarak melaut hanya berkisar 3-4 mill, jarak tempuh sekitar 1-2 jam untuk menjangkau lokasi penangkapan. Bagi nelayan yang memperoleh permodalan untuk melaut melalui langgan, maka pemasaran dikuasai oleh langgan, serta penentuan harga dan pemasaran semuanya dikendalikan oleh langgan. Sedangkan nelayan yang tidak memiliki ikatan pada langgan, maka jaringan sosial pemasaran hasil tangkapan dilakukan secara langsung melalui TPI Lontar. Transaksi di pelelangan, dilakukan mekanisme pengelompokan jenis dan ukuran ikan, dan kemudian diadakan penawaran harga secara terbuka dan disesuaikan dengan harga di pasaran.
\end{abstract}

\section{MARKETING SOCIAL NETWORKS OF TRADITIONAL FISHERMEN BANTEN}

\begin{abstract}
Traditional fisherman rely on seasonal condition when they do fishing, their fishing product, their capital, and social network marketing.The study aimed to investigate the characteristic of traditional fisherman. Their social system and their marketing strategies. It was a qualitative study using partisipative observation, in-depth interview, and documentation technique. The subjects of the study were capital owner, boat owner, fisherman, and officer of fish auction. The study showed that traditional fisherman community in Lontar did its fishing based on fishing equipment which consisted of rejung, net, reef fish, and clam. The boats capacity were about 15-17 pk, with 3-4 miles distance and 1-2 hours journey to fishing location. Traditional fishermen were highly depent on capital owner (langgan) whom they got the capital from and they gave the fishing products to. Moreover, langgan decided the price and fish marketting. Some of traditional fishermen could directly sold their fishing products themselves because they had their own capital. The fisherman community sold their fishing products in fish auction, which price was determinied by the kinds and sizes of the fishes.
\end{abstract}

(C) 2014 Universitas Negeri Semarang 


\section{PENDAHULUAN}

Komunitas nelayan merupakan kelompok masyarakat yang hidup dan berdiam di pesisir pantai secara turun temurun dengan menciptakan suasana kekerabatan. Sebagai komunitas yang mendiami daerah pesisir dan memiliki keahlian, nelayan sangat menggantungkan hidupnya dari hasil tangkapan yang dihasilkan. Komunitas nelayan seringkali berhadapan dengan ketidakpastian pendapatan dan tekanan musim paceklik ikan yang panjang. tetapi lebih dari itu mereka juga sering harus berhadapan dengan berbagai tekanan dan bentuk eksploitasi yang muncul bersamaan dengan berkembangnya proses modernisasi di sektor perikanan. Bila persoalan itu dihadapi oleh para nelayan secara mandiri, maka selama itu pula persoalan itu tidak akan bisa diselesaikan dengan baik.

Kelompok nelayan memiliki ketergantungan yang sangat tinggi terhadap kondisi alam pada saat melakukan kegiatan melaut. Menurut Kusnadi (2002) bahwa perangkap kemiskinan yang melanda kehidupan nelayan disebabkan oleh faktor-faktor yang kompleks. Faktor-faktor tersebut tidak hanya berkaitan dengan fluktuasi musimmusim ikan, keterbatasan sumber daya manusia, modal serta akses, jaringan perdagangan ikan yang eksploitatif terhadap nelayan sebagai produsen, tetapi juga disebabkan oleh dampak negatif modernisasi perikanan yang mendorong terjadinya pengurasan sumberdaya laut secara berlebihan. Kondisi itu terjadi secara langsung, sehingga jaringan sosial pada komunitas nelayan semakin kuat, karena adanya kepentingan dan saling menguntungkan.

Sebagian masyarakat nelayan tradisional melakukan usaha dalam bentuk skala kecil dan menengah. Secara empirikal, nelayan tradisional lebih banyak dari mereka yang bersifat subsisten dalam mempertahankan hidup keluarganya. Menjalani usaha dan kegiatan ekonominya untuk menghidupi keluarga sendiri dengan skala yang begitu kecil, sehingga hasilnya hanya cukup untuk memenuhi kebutuhan jangka waktu sangat pendek. Dalam berbagai keterbatasan akses jaringan sosial bagi nela- yan tradisional maka memerlukan bantuan orang yang berada di luar komunitasnya. Sebagaimana Lawang (2005) bahwa pada dasarnya jaringan sosial terbentuk karena adanya rasa saling tahu, saling menginformasikan, saling mengingatkan, dan saling membantu dalam melaksanakan ataupun mengatasi sesuatu. Intinya, konsep jaringan dalam capital social menunjuk pada semua hubungan dengan orang atau kelompok lain yang memungkinkan kegiatan dapat berjalan secara efisien dan efektif.

Memperkuat ketahanan hidup komunitas nelayan tradisional, maka kehadiran jaringan sosial pemilik modal sangat diperlukan untuk keberlangsungan usaha nelayan tradisional. Sebagai nelayan tradisional memiliki keterbatasan dalam menciptakan jaringan-jaringan sosial permodalan. Sebagaimana Damsar (2002) bahwa jaringan sosial merupakan hubungan-hubungan yang tercipta antarbanyak individu dalam suatu kelompok ataupun antar suatu kelompok dengan kelompok lainnya. Hubungan-hubungan yang terjadi bisa dalam bentuk yang formal maupun bentuk informal. Selain jaringan sosial permodalan, yang terpenting pula dan merupakan aspek paling akhir yaitu pemasaran hasil tangkapan.

Nelayan diperhadapkan oleh ketergantungan pemasaran, yaitu mekanisme pemasaran melalui pemilik modal dan pemasaran yang dilakukan melalui mekanisme pelelangan. Pemasaran melalui pemilik modal merupakan pilihan yang diperkuat melalui ketergantungan kontrak sosial melalui nilai-nilai kepercayaan. Ketergantungan nelayan pada pemilik modal, merupakan suatu ikatan-ikatan sosial yang menjadi pegangan untuk memperoleh pemenuhan kebutuhan hidupnya. Sebagaimana Harini (2012) bahwa peran jaringan sosial terhadap akses kerja para nelayan di Desa Suradadi yang akan berlayar ke luar negeri sangat berpengaruh, yaitu dengan cara berbagi informasi dan saling mempengaruhi satu dengan yang lainnya. Aktor yang paling menonjol serta berpengaruh dalam memunculkan fenomena perubahan dari miyangan ke longlenan adalah broker. Peranan brokerlah 
yang mempermudah akses seseorang menjadi longlenan dengan penghasilan yang cukup menggiurkan.

Komunitas nelayan tradisional yang bermukim di Lontar Kabupaten Serang Provinsi Banten, merupakan komunitas nelayan yang selama ini melakukan mekanisme pemasaran dalam dua bentuk, yakni pemasaran melalui ketergantungan pada pemilik modal dan pemasaran melalui sistem pelelangan. Penelitian ini akan mengkaji tentang karakteristik nelayan tradisional yang bermukim di Lontar. Selain itu akan mengkaji pula jaringan sosial proses pemasaran antarkelompok dan pemasaran melalui Tempat Pelelangan Ikan (TPI).

\section{METODE PENELITIAN}

Jenis penelitian yang digunakan dalam penelitian ini adalah jenis penelitian kualitatif. Penelitian kualitatif sebagai cara yang digunakan oleh peneliti dalam mengumpulkan data tentang jaringan sosial kelompok pemasaran hasil tangkapan pada komunitas nelayan tradisional di Lontar Kabupaten Serang Banten. Penelitian menggunakan metode deskripsi kualitatif. Penentuan Informan dilakukan dengan purposive sampling, dengan alasan bahwa penetapan informan dilakukan berdasarkan pada kriteria-kriteria tertentu dan disesuaikan dengan informasi yang dibutuhkan. Informan penelitian terdiri dari kelompok langgan (pemilik modal), pemilik perahu, nelayan, bakul, dan petugas TPI Lontar.

Fokus penelitian ini adalah mendeskripsikan karakteristik nelayan tradisional dan jenis alat tangkap yang digunakan dan proses penangkapan nelayan tradisional di Lontar Kecamatan Tanara Kabupaten Serang Provinsi Banten. Kemudian jaringan sosial antar kelompok dalam pemasaran hasil tangkapan nelayan tradisional di Lontar Kecamatan Tanara Kabupaten Serang Provinsi Banten, serta jaringan sosial pemasaran melalui TPI pada komunitas nelayan tradisional di Lontar Kecamatan Tanara Kabupaten Serang Provinsi Banten.

Pengumpulan data penelitian dilakukan melalui observasi berpartisipasi (participant observation), wawancara, dan studi dokumentasi. Proses analisis data dilakukan melalui transkrip data, pembuatan koding, penyimpulan sederhana, triangulasi, penyimpulan akhir data. Penelitian dilakukan di Lontar Kecamatan Tanara Kabupaten Serang Provinsi Banten, merupakan lokasi tinggal dan menetap nelayan tradisional dan bermukim di sekitar Tempat Pelelangan Ikan (TPI) Lontar.

\section{HASIL DAN PEMBAHASAN}

Nelayan tradisional yang berdomisili di perkampungan Lontar Kecamatan Tanara Kabupaten Serang memiliki karakteristik dalam menjalankan aktifitasnya sebagai nelayan. Karakteristik itu dapat diamati dari hasil tangkapannya berdasarkan pada kondisi jenis perahu dan alat tangkap yang digunakan. Alat tangkap yang dimiliki itu, akan mengarah pada kondisi berdasarkan pada jenis ikan yang menjadi sasaran tangkapannya. Nelayan tradisional di Kecamatan Tanara memiliki jenis perahu tradisional dengan kapasitas 16 PK. Keterbatasan kapasitas mesin dan jenis perahu yang berukuran kecil tidak menjadi Langgan dan rintangan untuk tetap melaut.

Nelayan mulai beroperasi sekitar jam o7.0o untuk melakukan penangkapan ikan berdasarkan pada jenis alat tangkap yang dimilikinya. Sebagai nelayan tradisional sebagian besar nelayan hanya mengandalkan lokasi penangkapan tidak terlalu jauh dari pesisir. Beberapa informan yang mengatakan bahwa lokasi penangkapan tidak terlalu jauh, jarak lokasi hanya memiliki kemampuan jangkauan sekitar 3 mill sampai 4 mill dari pesisir pantai. Perjalanan ke area zona aman ditempuh sekitar antara 2 jam. Sehingga kalau berangkat melaut sekitar jam 07.0o wib (berangkat pagi) dan kemudian kembali sekitar jam 12.00 Wib. Selain itu ada juga berangkat melaut sekitar jam 12.00 wib (berangkat siang) dan kembali sekitar jam 17.0o wib.

Sebagaimana Sodikin (5o tahun) profesi nelayan yang memakai alat tangkap menggunakan pukat rejung. Mengapa alat tangkap yang digunakan diberi nama rejung, karena nelayan menangkap ikan rejung. Kemampuan dalam mengakses alat 
tangkap sering diberi nama secara lokal dengan mengambil nama ikan yang ditangkap. Jaring rajungan yang digunakan oleh Sodikin dan beberapa nelayan lainnya menggunakan jaring rajungan. Jaring rajungan memiliki panjang antara 200 meter sampai dengan 300 meter. Bagi Sodikin penggunaan alat tangkap pukat rejung merupakan salah satu profesi yang sudah ditekuni sekitar 27 tahun menjadi nelayan khusus menangkap ikan rejung. Keahlian yang dimiliki sebagai penangkap ikan rejung tidak akan tergantikan sampai kapanpun dan masih bertahan hingga saat ini.

Lain halnya Suparman (52 tahun) dalam kegiatan penangkapan ikan menggunakan Jaring insang. Rancangan jaring ini berbentuk empat persegi panjang, mata jaring berukuran sama dilengkapi dengan pelampung pada bagian atas dan pemberat pada bagian bawah jaring. Penggunaan jaring insan digunakan dan bertujuan untuk menghadang gerombolan ikan. Pengoperasian jaring insang sangat sederhana, nelayan secara pasif dengan ukuran mata jaring yang disesuaikan dengan jenis ikan yang akan ditangkap, dan biasanya ukurannya dibuat dalam bentuk yang sangat minim. Secara spesifik alat tangkap ini terdiri dari tingting (piece) dengan ukuran mata jaring, panjang, dan lebar yang bervariasi. Dalam operasi biasanya terdiri dari beberapa tinting jaring yang digabung menjadi satu unit jaring yang panjang, dioperasikan dengan dihanyutkan, dipasang secara menetap pada suatu perairan dengan cara dilingkarkan atau menyapu dasar perairan.

Nelayan khusus penangkap kerang dilakukan Deden (56 tahun), kesehariannya sebagai nelayan terfokus pada penggunaan alat pengumpul kerang. Alat tangkap ini, pada umumnya didesain dengan pengoperasian yang sederhana dan target pengoperasiannya dilakukan dengan skala yang relatif kecil. Alat ini menurut informan, tidak mengganggu dan merusak lingkungan lainnya karena hanya ditujukan untuk menangkap target seperti kerang-kerangan. Teknologi sederhana yang digunakan disebut alat pengumpul kerang atau garuk (rake). Alat tangkap ini menurut informan sangat ra- mah dengan lingkungan dan tidak merusak alam.

Pukat ikan karang (muro-ami) adalah suatu alat penangkapan yang dibuat dari jaring, yang terdiri dari sayap dan kantong yang dalam pengoperasiannya dilakukan penggiringan ikan-ikan yang akan ditangkap agar masuk ke bagian kantong yang telah dipasang terlebih dahulu. Asep (47 tahun) kesehariannya hanya mengandalkan pukat ikan karang dalam melakukan operasi. Menurut informan bahwa alat ini cenderung tidak destruktif dan tidak merusak ekosistem, karena metode pengoperasiannya yang tidak sampai merusak karang. Penggunaan alat ini dilakukan oleh beberapa nelayan dengan berenang, mengejutkan ikan-ikan karang sambil membawa alat penggiring. Dinamakan pukat ikan karang karena tujuan utamanya adalah menangkap jenis-jenis ikan karang. Nelayan yang mengandalkan pukat ikan karang, diperlukan keahlian tersendiri untuk melakukan penangkapan. Pengoperasian pukat ikan karang diperlukan keahlian untuk berenang dan mengerti situasi dan kondisi lingkungan sekitarnya.

Nelayan dalam melakukan operasi penangkapan, memiliki awak sekitar 2-3 orang. Jumlah personil atau awak perahu tergantung pula pada alat tangkap yang digunakan. Nelayan yang memiliki awak 2 sampai dengan 3 orang biasanya nelayan menggunakan jaring insang. Ada juga nelayan hanya membutuhkan awak perahu sekitar 2 orang terutama nelayan menangkap kerang. Nelayan tradisional dalam melakukan operasi penangkapan, juga tergantung pada kondisi alam dan cuaca. Beberapa informan nelayan mengatakan bahwa cuaca dan kondisi alam sangatlah penting untuk melaut.

Nelayan tradisional di Lontar memiliki keyakinan menyatu dengan alam dalam melakukan operasioal penangkapan. Bagi mereka melaut adalah bagian dari proses hidupnya dan menjadikan komitmen untuk tetap mempertahankan hidupnya sebagai nelayan. Lokasi penangkapan dapat diketahui banyak atau tidaknya ikan dilihat dari tanda-tanda alam berdasarkan cerah atau 
tidaknya langit. Petunjuk itu diperoleh secara turun temurun, dan ilmu pengalaman itu tidak pernah salah dalam melakukan interpretasi lokasi penangkapan. Lokasi penangkapan yang hanya berjarak dekat, dan setiap hari melakukan operasional di laut, tidak menyurutkan semangat perjuangan bagi nelayan untuk tetap melaut.

Setelah perahu didaratkan di dermaga ikan langsung ditangani oleh awak kapal atau Anak Buah Kapal (ABK), maupun kelompok-kelompok kerja sukarela yang berada di sekitar tempat parkir perahu-perahu. Tempat pendaratan atau pelabuhan Lontar terdapat beberapa tenaga sukarela yang selalu siap menanti datangnya perahu. Tenaga sukarela itulah selalu ikut membantu para nelayan yang akan sandar perahunya. Mengapa bermunculan tenaga sukarela, karena nelayan seringkali ada yang parkir pada wilayah yang agak jauh sekitar 100-150 meter dari tempat sandar perahu. Jauhnya perahu itu bersandar diakibatkan oleh jumlah perahu yang menumpuk yang telah bersandar di dermaga pelabuhan.

Selama proses pembongkaran di darat dilakukan secara bergotong royong antara anak buah perahu. Kalau penjulan akan dilakukan di pelelangan maka hasil tangkapan disortir di pelataran pelelangan, dan kemudian dipilih dan dipisahkan menurut jenis ikan. Pemilihan dan pemisahan itu dilakukan agar ikan yang akan dilelang disesuaikan dengan harganya. Demikian pula halnya pada saat proses penimbangan diperlukan pemisahan berdasarkan pada jenis ikannya. Selain jenis ikan dilakukan pula pemilahan dan pemisahan berdasarkan ukuran besar kecil ikan hasil tangkapan. Pemisahan dan pemilahan dilakukan berdasarkan jenis ikan dan ukuran ikan, agar menyesuikan harga. Kalau nelayan yang menangkap hanya pada satu jenis ikan saja, maka lebih fokus pada ukuran dan mutu ikan itu sendiri.

Setelah melalui proses pemilahan dan pemisahan, maka kemudian dilakukan proses penimbangan di lapak masing-masing atau di pelataran Tempat Pelelangan Ikan (TPI) Lontar. Proses penimbangan dilakukan dengan sesuai standar dan disaksikan secara langsung oleh pihak pelelangan dan disaksikan secara langsung oleh nelayan dan beberap orang calon pembeli. Mekanisme proses transaksi dipelelangan harus melewati tahap pemisahan dan pemilahan dan kemudian selanjutnya dilakukan penimbangan. Setelah proses penimbangan sudah selesai dan nelayan merasa sudah tidak ada yang keberatan atas hasil timbangan, maka dilanjutkan proses pelelangan untuk menawarkan kepada calon pembeli. Pelelangan dilakukan secara terbuka dan tidak ada intervensi dari pihak manapun mengenai harga pelelangan.

Pelelangan ikan hasil tangkapan selalu berjalan dengan baik, oleh informan nelayan yang telah lama dan mengalami periode pelelangan ikan di TPI Lontar Kecamatan Tanara. Sebagian besar informan, terutama awak perahu yang selalu melakukan penjualan hasil tangkapannya di pelelangan ikan merasakan banyaknya keuntungan yang diperoleh dari pelelangan. Menurut informan Sodikin (5o tahun) bahwa menjual hasil tangkapan dipelelangan ikan TPI Lontar memiliki keuntungan, diantaranya dapat melakukan akses secara langsung dan jaringan secara langsung ke TPI. Selain itu keuntungannya kami sebagai nelayan mengetahui secara langsung mengenai angka harga pasaran. Harga jual di pelelangan disesuaikan dengan harga di pasaran, sehingga nelayan tidak merasa dirugikan.

Berdasarkan pernyataan informan bahwa tempat pelelangan ikan di TPI Lontar memiliki komitmen untuk saling terbuka pada nelayan terkait masalah harga. Prinsip keterbukaan itulah, nelayan juga merasa diberikan penghargaan dan dilibatkan dalam setiap proses pengambilan keputusan soal harga. Informan merasa sangat puas atas berbagai aturan main yang diberlakukan selama ini oleh pihak pengelola Tempat Pelelangan Ikan (TPI) Lontar. Proses yang sangat diharapkan bagi nelayan terkait proses transaksi di pelelangan harus memakai manajemen berbasis keterbukaan harga dan pelelangan sangat mendukung karena ada pada posisi di sekeliling pemukiman nelayan. Sebagaimana Agus Ruswandi dan Dewi Gartikastrategi (2013) mengatakan bahwa terkait keberadaan pelabuhan nelayan cen- 
derung lebih suka berlabuh pada pelabuhan yang lebih dekat dengan permukiman mereka.

Sebelum adanya Tempat pelelangan ikan di Lontar yaitu sekitar tahun 1980-an hingga akhir tahun 2000-an nelayan banyak tergantung penjualan pada langgan atau tergantung pada pemilik modal. Kehadiran pemilik modal (langgan) tersebut, memiliki posisi yang sangat kuat dalam menentukan nasib harga dari hasil tangkapan nelayan. Berkembangnya para langgan-langgan pada era tahun 1980 hingga tahun 1990an itu, karena penghasilan sangat menjanjikan untuk menjadi langgan. Sebagimana Deden (61 tahun) seorang langgan yang sudah berprofesi sekitar 30 tahun mengatakan bahwa sebagai langgan merupakan salah satu pekerjaan yang sangat menjanjikan untuk memperoleh penghasilan. Sebagai langgan, perlu memperhatikan berbagai kebutuhan nelayan baik berupa alat perlengkapan untuk melaut hingga bahan pokok kebutuhan keluarganya. Bagi nelayan yang menjadi binaan perlu bagi langgan untuk menyiapkan berbagai kebutuhan dan saling menguntungkan.

Kehadiran langgan sebagai jaringan sosial, ada nilai-nilai yang sangat melekat yang mereka pegang antara nelayan dan langgan. Di antaranya adalah nilai kepercayaan dari aspek kebutuhan material dan kebutuhan hidup yang lainnya untuk pemenuhan makan keluarga nelayan. Bagi langgan menaruh kepercayaan pada nelayan untuk memperoleh hasil tangkapan, dan sebaliknya nelayan menaruh harapan untuk memperoleh bantuan permodalan dan pemenuhan kebutuhan pokok tatkala sebelum berangkat melaut. Langgan selalu menunggu kehadiran nelayan yang mengharapkan bantuan berupa peralatan dan kebutuhan lainnya. Modal utama langgan pada jaringan sosial nelayan, adalah kepercayaan untuk mengembalikan modal yang sudah diberikan sebelumnya dengan transaksi hasil tangkapan.

Nelayan sebagai pekerja tidak memiliki pilihan lain untuk memperoleh permodalan, selain dari para langgan itu sendiri. Aturan main pun dibuat antara langgan dengan awak perahu dan atau komunitas nelayan terkait mekanisme kesepakatan sebelum melaut. Aturan yang berlaku selama ini, tetap berjalan sesuai kontrak, walaupun sebenarnya kontrak itu tidak tertulis. Kesepakatan kontrak yang diperkuat selama ini menjadikan mereka untuk saling mengikat dikemudian hari. Walaupun tidak ada komitmen yang tertulis, namun nelayan tidak mau melanggar peraturan yang telah disepakati secara bersama.

Berbagai keterbatasan yang dimiliki oleh nelayan untuk tetap mempertahankan hidup dan usahanya, maka satu-satunya jalan adalah menggantungkan diri pada pemilik modal. Posisi pemilik modal memiliki kekuatan yang sangat dominan dalam jaringan pemasaran hasil tangkapan. Penentuan harga dan jumlah hasil tangkapan semuanya diserahkan pada pemilik modal, tanpa memperhatikan sisi keterlibatan nelayan itu sendiri. Kehadiran nelayan dalam sistem langgan sebenarnya sampai saat ini masih tetap terjadi pada nelayan tradisional di Lontar. Sebagaimana informan Asep mengungkapkan bahwa sebagai nelayan khusus menangkap ikan karang, memiliki hubungan dengan salah seorang langgan yang membantu permodalan baik musim ikan maupun musim paceklik. Kondisi itu bagi Asep merupakan salah satu takdir yang sudah ditentukan untuk tetap bergantung para langgan yang selama ini menghidupinya. Keberadaan pemilik modal atau langgan sebenarnya memberikan kemudahan pada nelayan untuk mendapatkan permodalan dengan sistem ketergantungan satu sama lainnya.

Jaringan sosial pemasaran bagi komunitas nelayan pada masa ketergantungan pada langgan hanya terhenti pada pemilik modal itu sendiri. Nelayan hampir tidak pernah menikmati kebebasan dalam menentukan harga yang sebenarnya. Setelah awak perahu kembali dari melaut, maka hasil tangkapan langsung disetorkan pada pemilik modal (langgan). Langgan itulah yang memproses mulai dari sortir hingga penimbangan ikan dan sekaligus menentukan harga. Penentuan jenis ikan awak perahu tidak dilibatkan lagi dan hampir tidak 
punya hak suara dan hak berpendapat. Keberadaan langgan, bagi nelayan merupakan salah satu jaringan sosial yang memiliki kekuatan mengatur hidupnya.

Proses pemasaran yang dilakukan langgan secara langsung berhubungan dengan bakul-bakul yang mengumpulkan ikan hasil tangkapan untuk dipasarkan. Hubungan para langgan dengan bakul sangat erat kaitannya, karena saling menguntungkan antara satu dengan yang lainnya. Sistem yang dibangun para langgan juga saling menguntungkan dengan para bakul-bakul, sehingga harga juga ditentukan oleh para bakul dan bisa juga sebaliknya langgan yang menentukan harga. Aspek moral yang muncul dari sikap para pedagang tidak lepas dari munculnya keterlekatan baik antarsesama pedagang maupun dengan para pembeli. Menurut Granovetter dalam Damsar (2002) keterlekatan adalah tindakan ekonomi yang disituasikan secara sosial dan melekat (embedded) dalam jaringan sosial personal yang sedang berlangsung di antara para aktor. Ini tidak hanya terbatas pada tindakan aktor individual sendiri tetapi juga mencakup perilaku ekonomi yang lebih luas, seperti penetapan harga dan institusi-institusi ekonomi yang semuanya terpendam dalam suatu jaringan hubungan sosial.

Melalui jaringan sosial pemasaran sistem langgan ke bakul merupakan sistem yang bernilai hubungan yang sangat erat sehingga bagi mereka diperlukan saling kepercayaan. Namun jaringan sosial sistem langgan ke bakul bagi nelayan sangat merugikan, karena akses hanya terbangun dalam dua komunitas penguasa tersebut. Kehadiran kelompok penguasa pasar itu, nelayan hanya berada pada posisi sebagai pemasok bahan baku jualan. Sodikin mengungkapkan bahwa biasanya langgan memberikan pinjaman terlebih dahulu kepada nelayan sebagai modal melaut, setelah mendapat ikan, maka langgan yang berhak menjual ikan dan menentukan harga. Melalui mekanisme dan sistem ini, nelayan tidak mengetahui secara pasti berapa harga ikan yang dimilikinya. Nelayan hanya melihat prosesnya namun tidak memiliki kemampuan untuk membantah, dan hanya membenarkan apa

\section{kemauan langgan.}

Pada era awal tahun 2000-an mekanisme pemasaran ikan yaitu nelayan memiliki mekanisme yang baru berbasis pemasaran dengan sistem terbuka. Keuntungan yang diperoleh melalui meknisme itu, nelayan merasa memiliki perbandingan baru tentang harga jual. Selain itu melalui sistem itu nelayan lebih terlibat secara pribadi dalam menentukan harga dan menyaksikan secara langsung proses penjualan. Secara permanen sebenarnya pada tahun 2002 tempat Pelelangan Ikan di Lontar sudah berdiri, namun nelayan belum begitu banyak yang bergabung karena nelayan masih banyak yang tergantung hidupnya pada kelompokkelompok jaringan pemodal. Jaringan itu disebut Langgan dan bahkan ada yang langsung berhubungan dengan bakul (pengumpul ikan). Kondisi itu berjalan hingga tahun 2004, karena nelayan sebagian besar masih terikat utang atau kontrak dengan langgan dan maupun bakul.

Keberadaan Tempat Pelelangan Ikan di lontar yang didirikan tahun 2002, sebagai penyelamat dari kalangan langgan dan bakul, namun nelayan tidak memperdulikan keberadaannya karena beberapa faktor yaitu pertama TPI tidak dikelola dengan baik karena komunitas nelayan kelihatannya tidak tertarik secara langsung untuk menjual hasil tangkapannya. Kedua Keberadaan TPI tidak mampu menengahi berbagai persoalan yang dihadapi oleh nelayan. Menurut Boy (48 tahun) koordinator pengelola TPI Lontar bahwa pembangunan TPI pada tahun 2002 bukan pada posisi tempat pelelangan yang berada pada posisi saat ini. Kemudian pengelolaan tempat pelelangan yang lama bukan dikelola oleh Boy dan teman-temannya. Tempat pelelangan yang lama dengan yang baru memiliki jarak sekitar 250 meter. Tempat pelelangan yang baru yang dikelola saat ini dibangun sekitar 2004 dan bantuan dari anggaran Luar Negeri melalui hubungan atau perantara pemerintah daerah Kabupaten Serang.

Setelah terbentuknya dan terbangunnya tempat pelelangan ikan yang baru diberi nama TPI Lontar Kecamatan Tanara dengan rintisan kelompok masyarakat pesi- 
sir Lontar yang digerakkan secara lokal dan secara kebersamaan. Menurut Boy bahwa pada awal terbangun tempat pelelangan Lontar beliau dengan teman-temannya mengumpulkan beberapa nelayan Lontar untuk membicarakan berbagai persoalanpersoalan yang dihadapi oleh nelayan terkait tidak difungsikannya pelelangan sebagai media transaksi. Ternyata ada beberapa persoalan yang menghimpit oleh nelayan sehingga tidak menjual hasil tangkapannya pada pelelangan yang telah disiapkan sebelumnya. Lebih lanjut beliau mengungkapkan bahwa persoalan yang dihadapi nelayan saat itu adalah adanya ikatan yang kuat sudah terbangun antara nelayan dengan langgan serta bakul-bakul yang sudah terlebih dahulu memberikan permodalan.

Hal itu dipertegas oleh nelayan Suparman (51 tahun) bahwa sebenarnya hasil tangkapan ingin dipasarkan ke pelelangan saat itu. Namun pada periode itu, nelayan sudah memiliki jaringan sosial pemasaran yang telah mengikat secara turun temurun dan sangat tidak mungkin untuk ditinggalkan. Sebenarnya kalau ditinggalkan bisa saja, namun secara moralitas tidak akan mungkin dapat lepas dari ikatan jaringan pemasaran. Berdasarkan pernyataan informan itu, terungkap bahwa sebenarnya nelayan dimasa adanya tempat pelelangan sudah ada keinginan untuk lepas dari ikatan para langgan dan bakul. Faktor yang paling dominan sehingga tidak dapat lepas dari ikatan itu, karena nelayan merasa bahwa suatu ketika akan diperhadapkan oleh kondisi keterbatasan penghasilan. Melaut tidak akan menentu penghasilannya, hasil laut tidak selamanya akan diperoleh dengan hasil yang banyak, sehingga bisa terjadi nelayan tidak dapat memenuhi kebutuhan hidupnya. Maka pelarian yang sangat efektif memberikan perlindungan bagi nelayan adalah langgan.

Semenjak pelelangan berdiri pada tahun 2004, pengelola Tempat Pelelangan Ikan melalui Boy, dikumpulkan sebagian besar nelayan untuk rapat dan membicarakan keberlanjutan TPI Lontar. Maka salah satu terebosan yang dilakukan adalah meminta para nelayan untuk memasarkan hasil tangkapannya ke TPI. Namun kendala yang dihadapi bagi nelayan yang terbelit sangkutan dengan para langgan dan bakul. Hasil rapat saat itu menurut Boy, menghasilkan kesepakatan untuk melunasi dana nelayan yang diambil para nelayan dari langgan maupun bakul-bakul. Pelunasan dilakukan oleh pihak TPI melalui bantuan dari pemerintah. Kesepakatan itu memberikan suatu hal yang baru bagi nelayan, karena dapat lepas dari jeratan tali langgan yang selama ini mengikatnya.

Setelah mencapai kesepakatan, maka nelayan membuka akses untuk memberikan hasil tangkapannya untuk dijual di tempat pelelangan. Nelayan memiliki sangkutan dari pihak langgan sebenarnya tidak seberapa besar jumlahnya yaitu mulai dari 2 juta rupiah hingga yang paling terbesar 4 juta rupiah. Menurut Boy yang mendaftarkan diri untuk diberikan dana bantuan pelunasan jeratan utang pada langgan hanya sebagian kecil yaitu sekitar 50 dari ratusan nelayan tradisional di pesisir pantai Lontar. Ada juga nelayan tidak mau melakukan pelunasan dari langgan dengan alasan merasa sudah nyaman dengan kondisi yang dihadapi selama ini.

Kondisi tarik menarik untuk memisahkan nelayan dari langgan memiliki tantangan yang sangat luar biasa. Nelayan sudah merasa nyaman dengan kondisi kebiasaannya selama ini dan ketergantungannya sangat tinggi kepada langgan, karena dapat atau tidak dapat hasil tangkapan masih dapat meminjam uang dari langgan. Sedangankan kalau lepas dari langgan dan menjual ikan hasil tangkapannya pada tempat pelelangan TPI Lontar tidak akan ada yang menjamin apabila tidak memperoleh penghasilan. Karena pelelangan tidak menjanjikan dana tambahan untuk keluarga bagi nelayan disaat menghadapi masa tidak ada hasil tangkapan. Sebaliknya dibalik kegelisahan dan ketakutan nelayan tentang keterputusannya dengan langgan masih ada beberapa nelayan yang memiliki komitmen untuk menerima apapun resikonya apabila melepaskan diri dari langgan.

Seorang informan nelayan yang memiliki komitmen di tahun 2004 untuk ber- 
gabung dalam komitmen TPI adalah Subhi (51 tahun) mengatakan bahwa saat itu sekitar sepuluh tahun yang lalu saya secara pribadi mendaftarkan diri untuk bergabung pada kelompok TPI dengan syarat dana pengikat saya dari langgan sekitar 3 juta rupiah dapat diselesaikan. Kesepakatan dan keinginan beliau direalisasikan oleh pihak TPI sesuai dengan aturan yang berlaku. Salah satu aturan saat itu adalah melepaskan diri dari langgan dan hasil tangkapan sepenuhnya dipasarkan di TPI. Menurut Subhi bahwa sekitar $70 \%$ perahu adalah milik pribadi nelayan itu sendiri. Sehingga kalau mau berpindah tempat penjualan dari langgan ke TPI bisa saja terjadi, asalkan ada keberanian dalam resiko hidup dan berjuang sendiri.

Sebagaimana seorang nelayan yang berpindah penjualan hasil tangkapan ke TPI yaitu Adang (54 tahun) memiliki pengalaman yang sangat panjang dengan para langgan. Sejak tahun 2004 memutus mata rantai dengan para langgan yang selama ini mengikatnya. Sejak melepaskan diri dari langgan merasa memiliki kebebasan dalam menjual hasil tangkapannya. Selain itu, nelayan juga sudah dapat mengetahui secara langsung harga ikan di pasaran dan dapat melakukan penjualan langsung ke TPI. Sudah menjadi komitmen melepaskan diri dari jeratan langgan, sehingga dapat menikmati harga ikan sesuai dengan harga di pasaran.

Bey Pane (2010) bahwa penentuan harga dilakukan antara nelayan penjual dan pedagang/pengolah pembeli. Setiap nelayan penjual, yang baru kembali dari melaut, harus berhadapan langsung dengan banyak pembeli sekaligus atau mengeluarkan biaya untuk menggaji seorang "pengurus" atau orang kepercayaan untuk menjualkannya, selain juga mengeluarkan biaya retribusi lelang ke pihak pengelola TPI. Tempat Pelelangan Ikan (TPI) Lontar, nelayan menggunakan sebagai proses pelelangan ikan. Pelelangan ikan juga digunakan untuk bertransaksi bagi pembeli di luar dari pelelangan yang sengaja datang membeli ikan di pelelangan. Pembeli juga ada yang sengaja datang ke pelelangan secara individu untuk kebutuhan kesehariannya saja.
TPI setiap harinya dikunjungi banyak orang untuk melakukan transaksi. Pelelangan dibuka sekitar jam 09.0o wib sambil menungggu satu persatu nelayan berdatangan dari laut. Kondisi ini hampir terjadi setiap hari, pembukaan pelelangan tidak melihat jumlah perahu yang berangkat. Sedikit banyak nelayan yang akan memasarkan hasil tangkapannya, tempat pelelangan tetap melayani. Pola tawar menawar antara pembeli (pedagang pengecer, pengolah) dengan $b a-$ kul, dan ikan akan diputuskan terjual jika telah mendapatkan harga tertinggi. Sebagaimana Hendrik (2013) bahwa pemasaran ikan di Kecamatan Tanjung Beringin dan Kabupaten Serdang Bedagai disebabkan oleh berbagai faktor. Menurut keterangan nelayan yang tidak menjual ikan melalui TPI disebabkan karena mereka sudah terikat dengan tauke, sebagai pemilik kapal maupun tauke sebagai penanggung biaya selama mereka ke laut. Selain itu menurut keterangan nelayan lainnya jauhnya lokasi TPI dari tempat tinggal menyebabkan mereka tidak mau mendaratkan ikan di TPI.

Kondisi nelayan yang berdomisili di Lontar, telah memiliki kesadaran akan pemasaran hasil tangkapannya untuk sepenuhnya dijual di Tempat Pelelangan Ikan. Penjualan hasil tangkapan di TPI merupakan komitmen secara bersama-sama bagi nelayan untuk melepaskan diri dari pemilik modal langgan. Walaupun masih ada juga kelompok nelayan yang masih terikat pada pihak langgan. Kehadiran nelayan dan pihak yang terkait dengan sumber daya ikan tetap meramaikan TPI sebagai tempat transaksi hasil tangkapan. Kondisi keseharian pada Tempat Pelelangan Ikan Lontar sangat hidup dari kehadiran pihak nelayan dan pihak pengecer yang akan memasarkan secara langsung ke pembeli rumah tangga.

\section{SIMPULAN}

Karaketristik komunitas nelayan tradisional dapat ditemukan memiliki perbedaan dalam jenis ikan yang ditangkap. Alat tangkap yang digunakan sangat sederhana dengan berbahan lokal disesuaikan dengan pengetahuan dan pengalaman komunitas nelayan tradisional di Lontar. Jaringan so- 
sial antarkelompok dalam pemasaran hasil tangkapan, Bagi nelayan yang memiliki ketergantungan pada pemilik modal (langgan), maka hasil tangkapan sudah menjadi kewajiban untuk disetorkan pada langgan. Setelah hasil dikumpulkan, maka nelayan sudah terputus hubungannya dengan pasar. Penentuan selanjutnya adalah langgan menentukan harga dan proses pemasarannya. Pada posisi ini, nelayan tidak memiliki hak untuk berpendapat dan hanya memiliki posisi untuk menerima apa yang menjadi keputusan para langgan. Jaringan sosial pemasaran melalui TPI dilakukan secara terbuka dan nelayan memiliki kebebasan untuk menjual hasil tangkapannya. Keterlibatan nelayan mulai dari proses pembongkaran, penimbangan serta penentuan harga nelayan ikut serta menyaksikan keputusan dari pihak pelelangan. Pada proses penentuan harga, nelayan ikut serta melihat dan menyaksikan secara langsung transaksi yang dilakukan pihak pelelangan dengan kelompok pemasaran lainnya serta para pembeli. Pembayaran hasil penjualan dilakukan transaksi secara langsung antara pihak nelayan dengan pihak pengelola pelelangan setelah akhir dari hasil perhitungan ikan yang dilelang.

\section{DAFTAR PUSTAKA}

Agus, R. dan Dewi, G. 2013. Strategi Pengembangan Investasi Di Sekitar Pelabuhan Perikanan Tipe B Di Jawa Barat, Jurnal Akuatika 4 (1): 89-101

Anwar B.P. Kajian Kekuatan Hasil Tangkapan : Kasus Pelabuhan Perikanan Nusantara (PPN)
Pelabuhanratu Sukabumi. Jurnal Mangrove dan Pesisir 10 (1): 8-19

Amelia L., Christian R.D., Djuwita R.R.A. 2013 Manajemen Tenaga Kerja Tempat Pelelangan Ikan (TPI) Aertembaga Kota Bitung, Jurnal Ilmiah Akulturasi Agrobisnis Perikanan 1 (1): 11-14

Creswell, J, 2009. Research design: Qualitative, Quantitative and Mixed Methods Approaches, Sage, Thousand Oaks.

Damsar. 2002. Sosiologi Ekonomi. PT. Raja Grafindo Persada, Jakarta.

Fukuyama, F. 2005. Guncangan Besar. Kodrat Manusia dan Tata Sosial Baru.Terjamahan dari buku asli. The Great Disruption: Human Nature and the Reconstitution of Sosial Order. Gramedia Pustak Utama, Jakarta.

Harini, D.N. 2012. Dari Miyang Ke Longlenan : Pengaruh Jaringan Sosial Pada Transformasi Masyarakat Nelayan, Jurnal Komunitas 4 (2) : 178-19o

Hasibuan, J. 2006. Social Capital (Menuju Keunggulan Budaya Manusia Indonesia). MR-United Press, Jakarta.

Hendrik, 2013. Peranan Tempat Pelelangan Ikan (TPI) Dalam Pemasaran Ikan Hasil Tangkapan Nelayan Di Pangkalan Pendaratan Ikan (PPI) Kec. Tanjung Beringin Kab.Serdang Bedagai Provinsi Sumatera Utara. Jurnal Terubuk, 41 (1): 102-108

Johnson, DP. 1988. Teori Sosiologi Klasik dan Modern Penerbit PT. Gramedia. Jakarta.

Kusnadi. 2000. Nelayan: Strategi adaptasi dan jaringan sosial. Bandung: Humaniora Utama Press Bandung.

--2002. Konflik Sosial Nelayan, Kemiskinan dan Perebutan Sumberdaya Perikanan. Yogyakarta: LKiS.

Lawang, R.M.Z. 2005. Kapital Sosial Dalam Perspektif Sosiologi. Cetakan Kedua. FISIP UI Press, Depok

Mubyarto, L.S., dan Dove. 1984. Nelayan dan Kemiskinan; Studi Ekonomi-Antropologi di Dua Desa Pantai. Jakarta. Rajawali 